\title{
Dødelighet av alle årsaker i regioner og bydeler i Oslo: Sammenlikning med utvalgte europeiske land
}

\author{
Inger Stensvold, Marit Rognerud og Dag S. Thelle \\ Avdeling for epidemiologi og helseovervåking, Klinikk for forebyggende medisin, Ullevål sykehus, 0407 Oslo \\ Korrespondanse: Inger Stensvold, Statens helsetilsyn, Postboks 8128 Dep., 0032 Oslo \\ Telefon 22248905 Telefax 22248868 e-post inger.stensvold@helsetilsynet.dep.telemax.no
}

\begin{abstract}
SAMMENDRAG
Oslohelsa viste at det var store forskjeller i total dødelighet mellom regionene og bydelene i Oslo. Det er tidligere vist at dødeligheten i Oslo for menn har hatt en noe gunstigere utvikling enn landet for øvrig. I foreliggende artikkel blir det presentert sammenlikninger av dødelighet innen Oslo med flere europeiske land. Videre vises analyser av endring i totaldødelighet hos menn og kvinner i fire regioner for to perioder, samt årlig endring hos menn i 25 bydeler for perioden 1990 til 1996.

For en treårsperiode 1990-92 har vi sammenliknbare dødelighetsdata for aldersgruppen 45-74 år med europeiske data fra tolv land. Total dødelighet i Ytre vest er lavest innen Oslo, men noe høyere enn i Island for menn og i Frankrike for kvinner. Dødeligheten i Indre øst i Oslo ligger omtrent på samme nivå som i Polen for begge kjønn, henholdsvis 2,1 (menn) og 1,9 (kvinner) ganger høyere enn i Ytre vest. I perioden 1990-96 var det en årlig prosentvis nedgang i dødelighet for Oslo som helhet på 3,2\% for menn og 0,3\% for kvinner. Dødeligheten i Indre øst og Indre vest viste en økning for kvinner i denne perioden.

Det blir diskutert mulige forklaringer på de observerte forskjellene innen Oslo og landene i Europa: 1) ulike insidensrater av f.eks. hjerte-karsykdommer og kreft; 2) forskjellig letalitet ved kroniske fatale sykdommer; 3) selektiv innflytting til billigere bydeler av personer med høyere risiko for å utvikle sykdom, eller utflytting av friskere individer til andre regioner og land; og 4) ulike levekår på grunn av boforhold, miljø og arbeidssituasjon.

For å kunne forklare mekanismene bak de store forskjellene i dødelighet, må vi ha data om enkeltindivider med hensyn til levevaner, livsstilsfaktorer, opplevelse av egenverd, bo- og nærmiljøforhold samt bruk av helsetjenester.
\end{abstract}

Stensvold I, Rognerud M, Thelle DS. Mortality from all causes in several areas within the city of Oslo. Comparison with 12 European countries. Nor J Epidemiol 1998; 8 (1): 21-28.

\section{ENGLISH SUMMARY}

The «Oslo Health Report» showed that there are striking differences in mortality rates in the four geographic regions and 25 local authorities within the City of Oslo. Previous analyses have shown that the excess mortality for men in Oslo compared to the whole country of Norway has been reduced during the time period 1975 to 1994 . In this paper annual changes in total mortality rates for men in the 25 local authorities in Oslo are presented for the time period 1990 to 1996. We have also compared mortality data for the age-group 45-74 years for the three-year period 1990 to 1992 with corresponding European figures.

Total mortality rates in the Outer West region are lowest within Oslo, but slightly higher than the average rates for men in Iceland, and women in France who both have low rates. Mortality rates in the Inner East region are approximately at the same level as in Poland for both sexes, 2.1 and 1.9 times higher than in the Outer West region for men and women respectively. During 1990 to 1996 the annual decrease in total mortality rates in Oslo were $3.2 \%$ for men and $0.3 \%$ for women. Inner East and Inner West showed an increase in mortality rates for women in this period.

We see some possible explanations for the observed differences within Oslo and between the countries: 1) different incidence rates of cardiovascular diseases and cancer, 2) different case-fatality ratios for some of the major chronic diseases, 3) selective movement of sicker and healthier individuals between regions and countries and 4) bad living conditions, pollution, problems in relation to work.

In order to explain the mechanisms behind these large observed differences in mortality rates, we need data at the individual level on lifestyle, self-perceived health, living and social conditions as well as the availability and use of health care services. 


\section{INNLEDNING}

Forskjellene i total dødelighet innen Oslo er bekrevet av flere (1-3) og senest i Oslohelsa 1998 (4). I sistnevnte rapport er aldersjustert dødelighet $i$ aldersgruppen 20-74 år presentert for 25 bydeler og fire regioner for perioden 1991-94. For menn var dødeligheten 3,3 ganger høyere i bydelen med høyest relativt til bydelen med lavest dødelighet. For kvinner var forholdet 2,1. Overdødelighet i Indre øst i forhold til Ytre vest ser ut til å eksistere for begge kjønn, alle aldersgruppene og for de fleste store dødsårsakene (4).

Til dels store forskjeller i utviklingen av dødelighet av alle årsaker og av kardiovaskulære sykdommer mellom europeiske land har vært vist (5-7). I den anledning har styret i «The European Society of Cardiology» tatt initiativ til en større utredning om den seneste utviklingen av dødelighet av alle årsaker og av kardiovaskulær sykdom i Europa, for å kunne evaluere belastningen («burden») av kardiovaskulær dødelighet i Europa (Task Force report (8)). I denne utredningen er det presentert dødelighetsdata fra 30 europeiske land for menn og kvinner, 45-74 år for perioden 199092, samt utviklingen over tid for perioden 1970-92.

Formålet i den foreliggende artikkelen er å sammenlikne total dødelighet i Oslo's regioner/bydeler med tilsvarende data fra europeiske land (8), samt å studere utviklingen i dødelighet over tid for perioden fra 1990 til 1996.

\section{MATERIALE OG METODER}

Dødelighetsdata og befolkningsdata ble levert fra Statistisk kontor i Oslo for årene 1990 til 1996, separat for hvert kalenderår, 25 bydeler, for hvert kjønn og i 1-års aldersgrupper. Aldersstandardisering (basert på 5-års aldersgrupper) ble utført med direkte metode med to ulike standarder. Ved sammenlikning med europeiske land ble WHO's europeiske standard benyttet, mens Norges befolkning pr. 1.1.1981 ble brukt som standard ved analyser av endringer $\mathrm{i}$ fire regioner for to tidsperioder, for å kunne sammenlikne med data fra Oslohelsa (4).

Prosentvis årlig endring i bydelene av totaldødelighet, for aldersgruppen 45-74 år, i perioden 1990-96 ble estimert ved lineær regresjon. Avhengig variabel var dødelighetsratene for hvert enkelt år og i seks 5årige aldersgrupper, log-transformert. De uavhengige variable var alder (5-års grupper) og kalenderår.

\section{Inndeling av Oslo i 4 regioner}

For å dele inn Oslo i større enheter enn bydelene har vi gruppert bydelene etter sosiale og økonomiske indikatorer i 4 regioner (4), slik:

- Ytre vest: Bydel 7, 8, 21-25 + 27 - villastrøk med en velutdannet og velstående befolkning.

- Indre vest: Bydel 1-3 + 26 - relativt velstående og etablerte sentrumsområder.
- Ytre øst: Bydel 9-20 - hovedsakelig drabantbyer hvor utdannings- og inntektsnivået er forholdsvis lavt.

- Indre øst: Bydel 4, 5 og 6 - sentrumsbydeler med høy andel arbeidsledige, lavt inntektsnivå og høy andel med ikke-vestlige innvandrere.

Av Oslos folkemengde på omlag 495.000 innbyggere (i 1994) bor det 77.000 i Indre øst, 212.000 i Ytre øst, $71.000 \mathrm{i}$ Indre vest, og $135.000 \mathrm{i}$ Ytre vest.

\section{RESULTATER}

\section{Total dodelighet, menn og kvinner 45-74 år - sammenlikning med europeiske land}

Figur 1 viser variasjonen i total dødelighet mellom bydelene i Oslo framstilt kartografisk. Her er brukt aldersjusterte rater for aldersgruppen 45-74 år i perioden 1990-92. Det bemerkes at det i Oslohelsa (fig. 4.1.3-3) ble brukt aldersgruppen 20-74 år for perioden 1991-94. Fordelingen av dødelighet mellom bydelene i figur 1 er omtrent den samme som for den videre aldersgruppen og tidsperioden brukt i Oslohelsa (4). Dødeligheten for menn i alder 45-74 år bosatt på Sagene (bydel 4) og Grünerløkka-Sofienberg (bydel 5) er 3,4 ganger høyere enn for menn på Vinderen (bydel 23). Tilsvarende for kvinner er dødeligheten i Gamle Oslo (bydel 6) og på Romsås (bydel 18) 2,3 ganger høyere enn for kvinner på Ekeberg-Bekkelaget (bydel 7) og Nordstrand (bydel 8).

Tabell 1 viser aldersspesifikk dødelighet i tre 10års aldersgrupper for fire regioner i Oslo og land i Europa med høyest og lavest dødelighet i samme periode (8). Nivået i Oslo ligger $12-16 \%$ over nivået for Norge i de to høyeste aldersgruppene både for menn og kvinner, mens dødeligheten for kvinner og menn i alder 45-54 år ligger ca. 30\% høyere i Oslo enn i Norge.

Figur 2 viser aldersjusterte rater for dødelighet av alle årsaker for fire regioner i Oslo og noen europeiske land for menn og kvinner. Ratioen mellom ytterpunktene i Europa er 2,5 for menn og 2,1 for kvinner, og dette er noe høyere enn mellom Oslo Indre øst og Ytre vest (2,1 for menn og 1,9 for kvinner).

\section{Utvikling av dodelighet over tid}

Tabell 2 viser dødeligheten i Oslo i fire regioner og i to perioder for menn og kvinner 20-74 år. Det har vært en nedgang i dødelighet for menn på $11 \%$ (95\% konfidensintervall: $7-16 \%)$ og for kvinner på 5\% (0-11\%). For menn var det en nedgang i alle de fire regionene, prosentvis høyest i Ytre vest $(16 \%)$ og lavest $\mathrm{i}$ Indre vest $(4 \%)$, hvilket medfører at forholdet mellom Ytre vest og Indre øst har økt ubetydelig fra 2,05 i 1990-92 til 2,13 i 1993-96. For kvinner har det vært en økning i dødeligheten både i Indre øst og vest, mest i Indre øst med 7\%, mens dødeligheten i Ytre øst har gått mest ned med 9\%. Forholdet mellom dødeligheten i Ytre 
Figur 1. Dødelighet av alle ărsaker i Oslo 1990-92, aldersgruppen 45-74 år

MENN

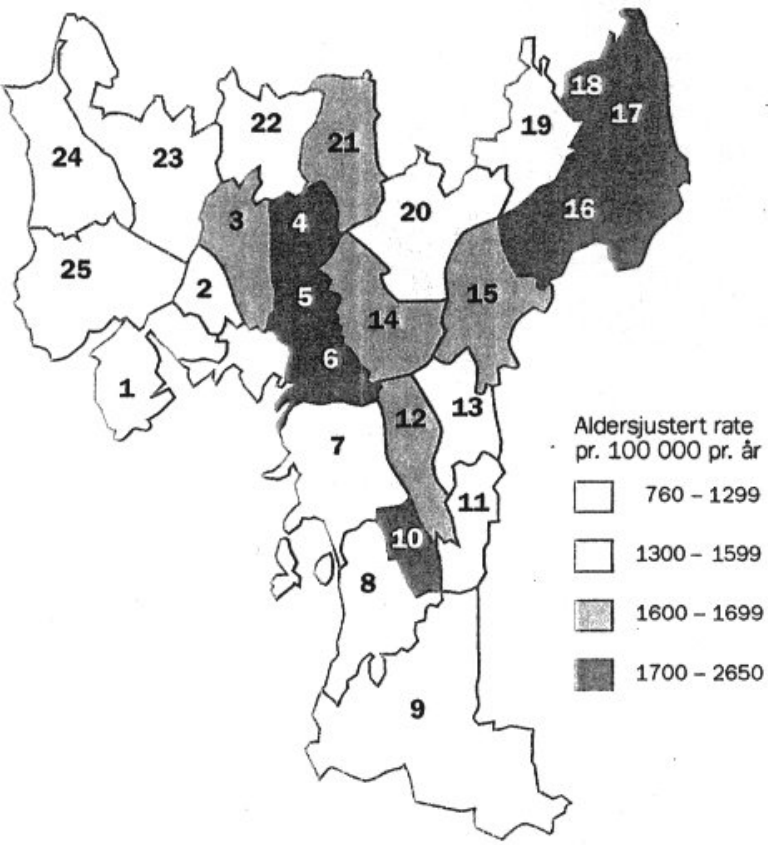

KVINNER

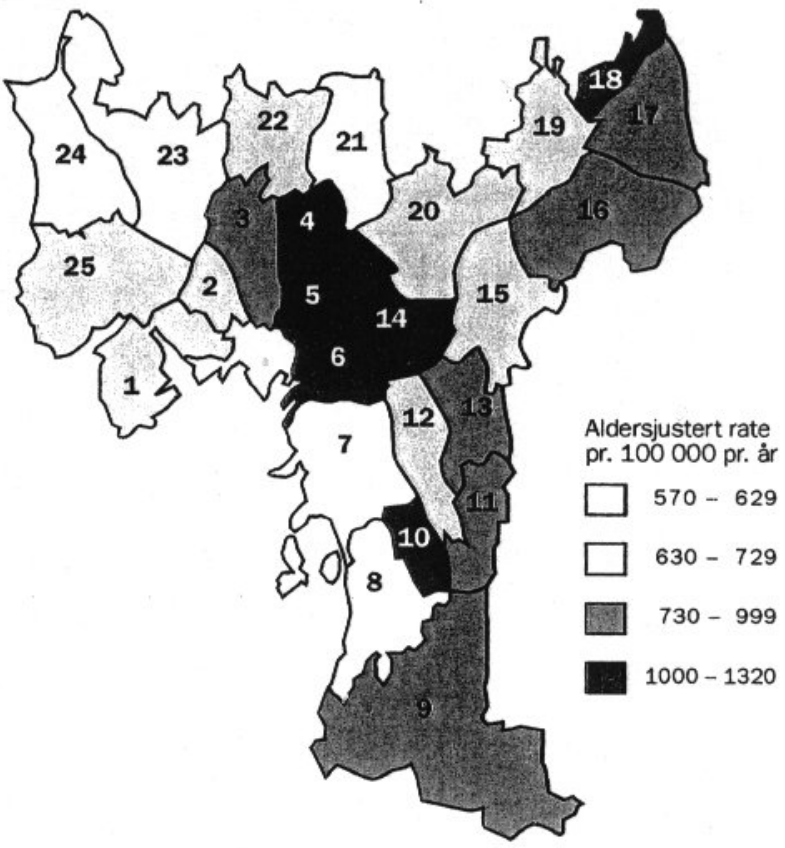

Figur 2. Dødelighet av alle årsaker i noen europeiske land og i Oslo, 1990-92

MENN 45-74 år

Aldersjustert rate pr. 100000 pr. âr

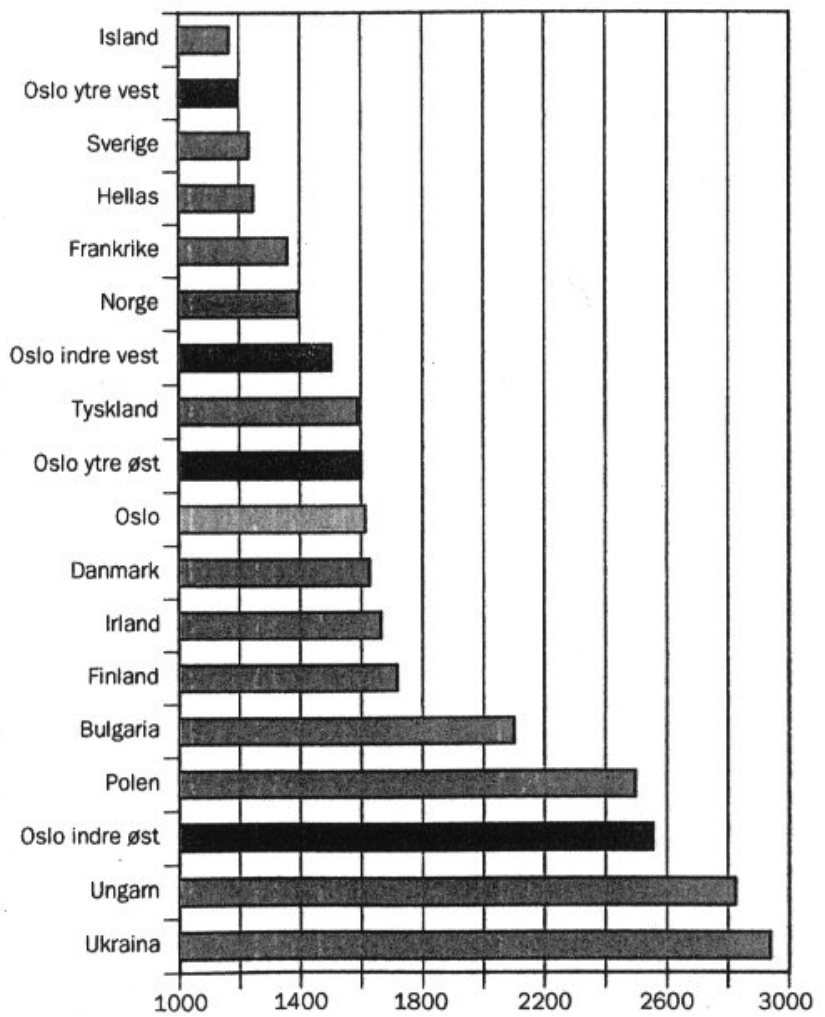

KVINNER 45-74 år

Aldersjustert rate pr. 100000 pr. àr

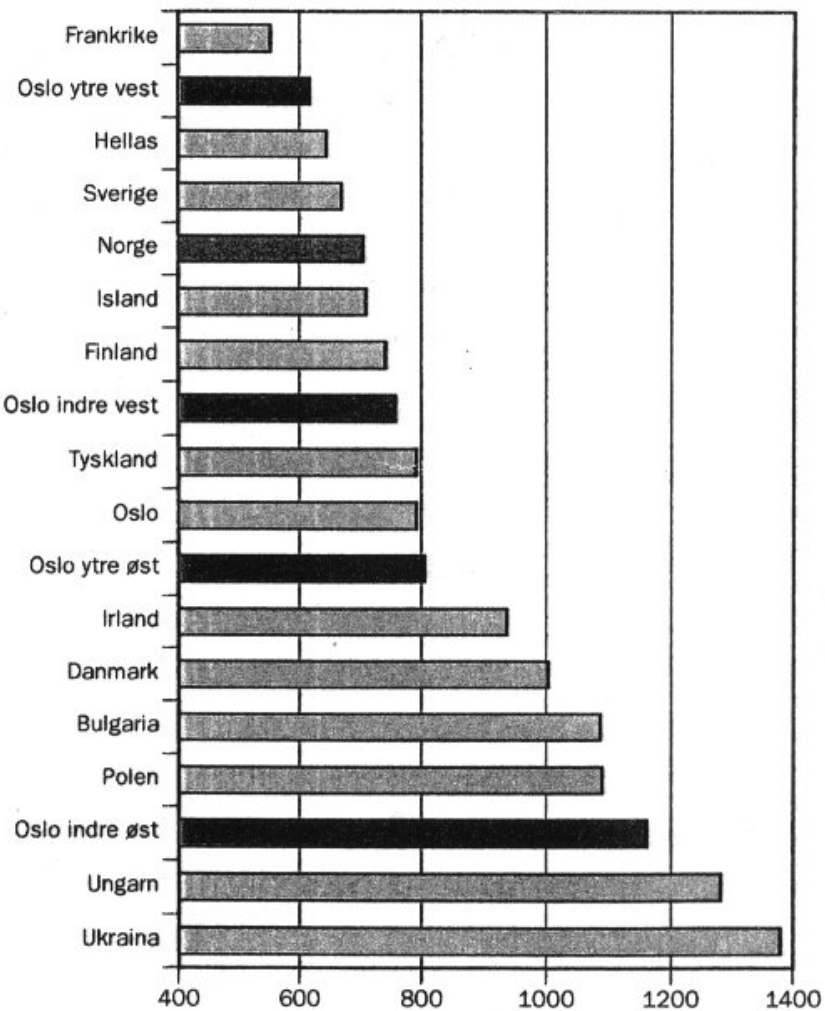


vest og Indre øst har økt noe mer for kvinner, fra 1,80 til 2,06, men denne økningen er ikke statistisk signifikant.

Tabell 1. Dødelighet av alle årsaker, 1990-92. Menn og kvinner, 45-74 år (Rater pr. 100.000 personår).

\begin{tabular}{lrrrr}
\hline & \multicolumn{3}{c}{ Aldersgrupper (år) } & \multirow{2}{*}{$\begin{array}{c}45-74 \text { år } \\
\text { aldersjustert }\end{array}$} \\
\cline { 2 - 4 } & $45-54$ & $55-64$ & $65-74$ & \\
\cline { 2 - 4 } Ytre vest & 330 & 1079 & 3207 & 1196 \\
Indre vest & 540 & 1268 & 3931 & 1504 \\
Ytre øst & 578 & 1451 & 3947 & 1602 \\
Oslo & $\mathbf{5 6 9}$ & $\mathbf{1 4 8 4}$ & $\mathbf{4 0 0 1}$ & $\mathbf{1 6 1 4}$ \\
Indre øst & 994 & 2567 & 5801 & 2557 \\
& & & Kvinner & \\
Ytre vest & 203 & 540 & 1659 & 617 \\
Indre vest & 327 & 664 & 1914 & 758 \\
Oslo & $\mathbf{3 1 4}$ & $\mathbf{7 1 8}$ & $\mathbf{1 9 9 2}$ & $\mathbf{7 9 2}$ \\
Ytre øst & 317 & 721 & 2014 & 805 \\
Indre øst & 574 & 1169 & 2531 & 1161 \\
\hline
\end{tabular}

Tilsvarende rater for noen europeiske land, lavest og høyest dødelighet, samt Norge

\begin{tabular}{lrrrr} 
& \multicolumn{4}{c}{ Menn } \\
Island & 379 & 1072 & 2901 & 1169 \\
Norge & 433 & 1319 & 3442 & 1396 \\
Ukraina & 1516 & 3000 & 5693 & 2940 \\
& & & Kvinner \\
Frankrike & 247 & 528 & 1198 & 552 \\
Norge & 242 & 650 & 1719 & 705 \\
Ukraina & 536 & 1280 & 3219 & 1379 \\
\hline \multirow{2}{*}{ Aldersjusterte rater (europeisk standard) pr. 100.000 personår }
\end{tabular}

Figur 3 viser den årlige prosentvise endringen $\mathrm{i}$ total dødelighet for menn, alder 45-74 år, i 25 bydeler. Tilsvarende analyse er ikke gjort for alle bydelene for kvinner, på grunn av få eller ingen dødsfall i enkelte aldersgrupper i mange av årene i perioden 1990-96. Den årlige prosentvise nedgangen i dødelighet for menn på 7-11\% i bydelene Manglerud (bydel 12), Furuset (bydel 16) og Grefsen-Kjelsås (bydel 21) er statistisk signifikant, mens det for øvrig (bortsett fra Oslo som helhet) ikke er signifikante endringer.

For Oslo var den årlige prosentvise nedgangen på $3,2 \%$ for menn og $0,3 \%$ for kvinner. Den europeiske studien har presentert data for en lengre periode, fra 1970 til 1992, og finner de største årlige nedgangene i Finland for menn $(1,7 \%)$ og i Spania for kvinner $(2,2 \%)$, begge endringer var statistisk signifikante (8). Også for Norge er det i denne perioden påvist en signifikant årlig nedgang i total dødelighet på ca. 1\% pr. år for begge kjønn.

\section{DISKUSJON}

\section{Sammenlikning av dodeligheten i Oslo med land $i$ Europa}

Dødelighet av alle årsaker (total dødelighet) for menn og kvinner i alderen 45-74 år i fire regioner i Oslo er sammenliknet med tilsvarende tall for tolv land $\mathrm{i}$ Europa (8). Innen Europa har Ukraina de høyeste dødelighetsratene både for menn og kvinner, 2,5 ganger høyere enn menn på Island og 2,5 ganger høyere enn kvinner i Frankrike (8). Forskjellene mellom regionene i Oslo er ikke fullt så store, men

Tabell 2. Dødeligheten i 4 regioner i 1990-92 og 1993-96. Aldersgruppen 20-74 år.

\begin{tabular}{|c|c|c|c|c|c|c|c|c|}
\hline & \multicolumn{4}{|c|}{ 1990-92 (3 år) } & \multicolumn{4}{|c|}{ 1993-96 (4 år) } \\
\hline & $\begin{array}{l}\text { Antall } \\
\text { døde }^{1}\end{array}$ & Rate $^{2}$ & Ratio $^{3}$ & $\begin{array}{c}\text { Konfidens- } \\
\text { intervall }\end{array}$ & $\begin{array}{l}\text { Antall } \\
\text { døde }^{1}\end{array}$ & Rate $^{2}$ & Ratio $^{3}$ & $\begin{array}{c}\text { Konfidens- } \\
\text { intervall }\end{array}$ \\
\hline & \multicolumn{8}{|c|}{ Menn } \\
\hline Ytre vest & 853 & 744 & 1 & & 966 & 642 & 1 & \\
\hline Indre vest & 499 & 929 & 1,25 & $(1,12-1,39)$ & 624 & 898 & 1,40 & $(1,26-1,55)$ \\
\hline Indre øst & 803 & 1523 & 2,05 & $(1,85-2,25)$ & 945 & 1370 & 2,13 & $(1,95-2,33)$ \\
\hline Ytre øst & 1843 & 984 & 1,32 & $(1,22-1,43)$ & 2181 & 889 & 1,38 & $(1,28-1,49)$ \\
\hline \multirow[t]{2}{*}{ Oslo } & 4097 & 993 & & & 4813 & 893 & & \\
\hline & \multicolumn{8}{|c|}{ Kvinner } \\
\hline Ytre vest & 558 & 385 & 1 & & 674 & 359 & 1 & \\
\hline Indre vest & 364 & 463 & 1,20 & $(1,05-2,03)$ & 431 & 469 & 1,31 & $(1,16-1,47)$ \\
\hline Indre øst & 452 & 691 & 1,80 & $(1,58-2,03)$ & 535 & 740 & 2,06 & $(1,84-2,31)$ \\
\hline Ytre øst & 1179 & 497 & 1,29 & $(1,17-1,43)$ & 1374 & 455 & 1,27 & $(1,16-1,39)$ \\
\hline Oslo & 2595 & 489 & & & 3044 & 465 & & \\
\hline
\end{tabular}

${ }^{1}$ Differansen i antall døde for Oslo totalt og summen av de 4 regionene utgjøres av personer uten fast bopel eller uten oppgitt bydelsnummer.

${ }^{2}$ Aldersjusterte rater pr. 100.000 personår (Standard: Norges befolkning pr. 1.1.1981).

${ }^{3}$ Ratio mellom dødelighetsrater med raten i Ytre vest som referanse. 
Figur 3. Arlig prosentvis endring i dødelighetsrater

for alle årsaker i 1990-96. Menn, alder 45-74 år

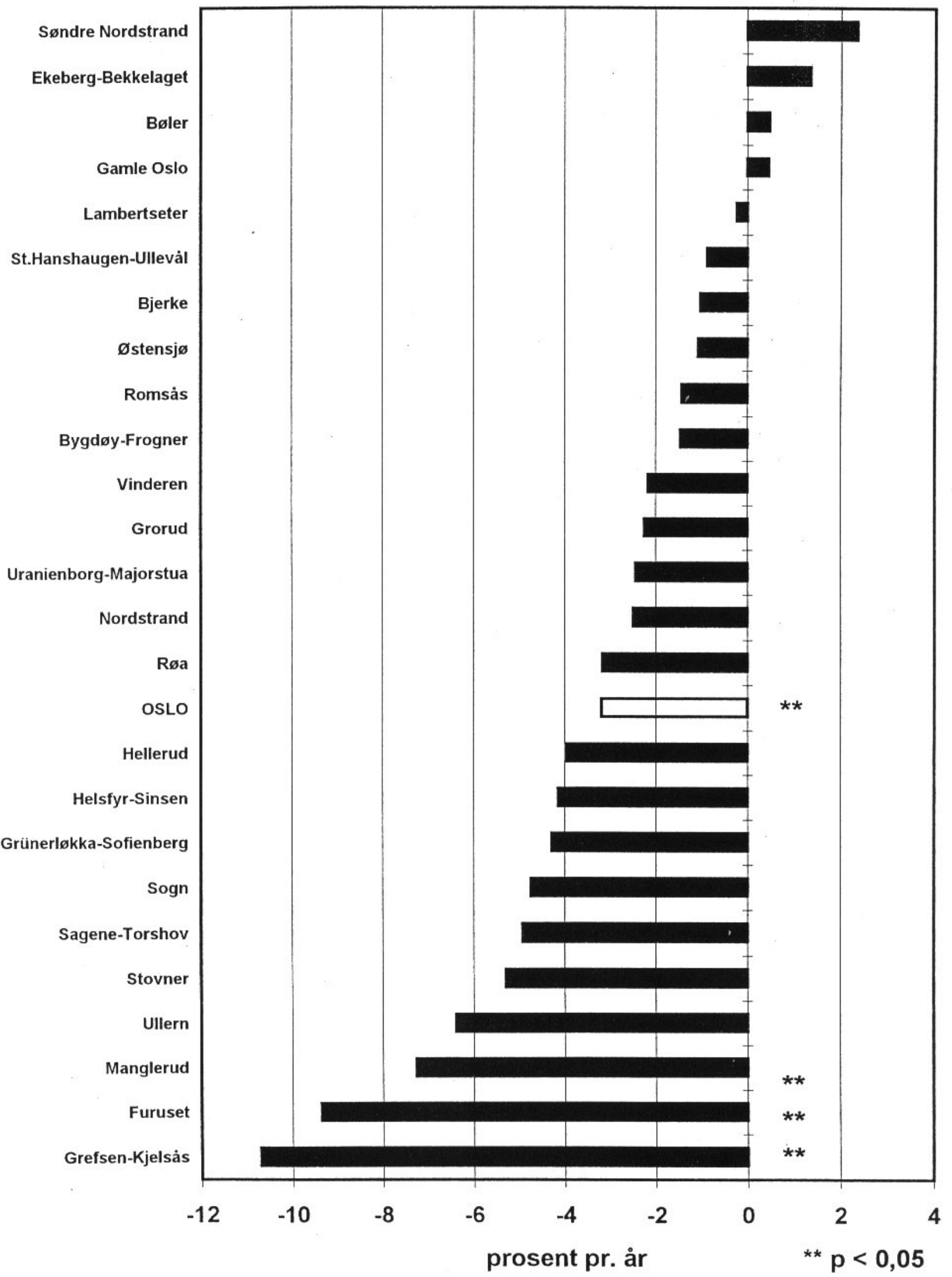


allikevel større enn mellom fylkene i Norge. For perioden 1990-94 hadde Finnmark høyest og Sogn og Fjordane lavest dødelighet både for menn og kvinner. Forholdet var 1,5 for menn og 1,3 for kvinner for alle aldersgrupper samlet (9).

Datagrunnlaget for de sammenlikningene som er presentert i artikkelen er offisiell statistikk basert på dødsmeldingene. Forskjeller mellom ulike land i årsaksspesifikke dødsrater kan som kjent bero på ulikheter i diagnosekriterier og koding av opplysningene på meldingene. De totale dødsrater vil ikke influeres av dette, og kan derfor brukes som validitetsindikator på årsaksspesifikke dødsrater så fremt det er tale om svært hyppig forekommende dørsårsaksgrupper. Blant de yngre og middelaldrende vil voldelige dødsfall samt død av hjerte-karsykdommer være dominerende dødsårsaker, mens man i noe høyere alder ser større hyppighet av kreftsykdommer.

Den europeiske sammenlikningen er begrenset til tidsperioden 1990-92 og gir ikke muligheter til å uttale seg om utviklingstrekk. Sammenlikningene kan dermed sees på som en tverrsnittstudie av dødeligheten mellom ulike populasjoner. I hvilken grad ulikhetene representerer en økning eller et fall i dødelighet kan man derfor bare gi indirekte og til dels spekulative svar på. Sammenlikningen mellom regioner i Oslo og ulike land i Europa tilslører dessuten den variasjonsbredde som også eksisterer innen disse landene. Fra kartene i europeisk helseatlas kan man avlese forskjeller som tilsvarer 1,3-2 ganger høyere dødelighet mellom enkelte regioner innen landene (7). En økologisk studie fra England viser en ratio på ca. 2 mellom regioner med høyest og lavest dødelighet (10).

\section{Forskjeller innen Oslo}

Gjestland og Moen har beskrevet øst-vest forskjellene i Oslo (indre by) for perioden 1971-80 og sammenliknet med perioden 1930-39 (2). I aldersgruppen 4069 år var overdødeligheten i Indre øst (i forhold til Indre vest) $14 \%$ for menn og $28 \%$ for kvinner i perioden $1930-39$ og tilsvarende $46 \%$ for menn og $28 \%$ for kvinner i 1971-80. I foreliggende undersøkelse for aldersgruppen 45-74 år er dødeligheten (1990-92) i Indre øst $70 \%$ høyere for menn og 53\% høyere for kvinner enn $\mathrm{i}$ Indre vest.

Grensene for de to regionene i indre by har imidlertid endret seg noe fra 1930 til 1990-årene. Indre vest var i 1930-39 en del av gamle Aker og etter byutvidelsen i 1948 kom områdene Marienlyst, Ullevål og Blindern med i Indre vest (2). Videre har Bygdøy blitt inkludert i Indre vest etter bydelsomleggingen i 1985. I begge perioder er altså områder fra Ytre vest med lavere dødelighet enn i indre by slått sammen med Indre vest. Dette kan være med på å forklare noe av de økende forskjellene mellom øst og vest $\mathrm{i}$ indre by. Nærmere analyser av aldersspesifikke rater og mer identiske geografiske områder er nødvendige for å kunne fastslå om øst-vest forskjellene i dødelighet fra 1970-årene til 90-årene har økt i Oslo. Dette arbeidet er igangsatt.

En studie av dødelighetsforskjeller innen Oslo i forhold til yrkesaktivitet fra 1980-85 viste at dødeligheten i Indre øst var omtrent dobbelt så høy som i Ytre vest (kun tre bydeler: 23-25) for både menn og kvinner i aldersgruppen 20-64 år (11). Forskjellene minket imidlertid for den gruppen som var yrkesaktiv, og overdødeligheten for yrkesaktive menn var $68 \%$ og for kvinner 52\% (Indre øst i forhold til Ytre vest). For faglærte mannlige arbeidere var den tilsvarende overdødeligheten «bare» $25 \%$ (11).

\section{Mulige forklaringer på forskjeller i dodelighet mellom regioner/land}

Forskjeller i dødelighet mellom ulike grupper av samme alder og kjønn kan oppstå enten ved at insidensratene er ulike, eller ved at letaliteten ved de store dødsårsakene varierer. Dersom det siste skal være forklaringen må man forutsette at individene i varierende grad blir tatt hånd om av behandlingsapparatet, og at kvaliteteten på tjenestene varierer. Når det gjelder forskjeller mellom land i Europa er dette en sannsynlig forklaring, spesielt når man sammenlikner land med meget ulik politisk og sosial situasjon. Forskjeller i letalitet kan også skyldes at forhold som sosial støtte, evne og mulighet for egenomsorg, og stress pga. dårlig økonomi kan påvirke prognosen ved alvorlig sykdom $(12,13)$.

Kriteriesystemet i Oslo skal sikre at bydelene med høyest dødelighet og størst behov for helsetjenester (med utgangspunkt i sosiale og demografiske kriterier) gis størst ressurser til primærhelsetjenester (14). Forskjellen i dødelighet skyldes derfor neppe vesentlige forskjeller i det medisinske behandlingstilbudet og reflekterer nok heller ulikheter i sykdomsinsidens. Det kan imidlertid tenkes at folk med lavere utdanning og sosial status ikke er like raske til å oppsøke helsetjenesten ved alvorlig sykdom. Hvis de kommer senere til behandling, kan det medføre dårligere prognose og høyere dødelighet ved alvorlig sykdom. Man kan få en indikasjon på at dette er tilfelle ved å studere frammøte ved den offentlige mammografiundersøkelsen i Oslo. Det er dårligst frammøte i bydelene i Indre øst (ca. $50 \%$ ), mens frammøtet i Ytre vest er ca. 70\%. I tillegg er det mange i disse bydelene som benytter seg av private tilbud, og derved undersøkes tidligere og oftere enn kvinner i de østlige bydelene (personlig meddelelse Hege Wang, Kreftregisteret).

En annen mulig forklaring på regionale forskjeller er selektiv flytting fra et område til et annet. Oslo kjennetegnes av en omfattende flytting. Totalt var det $\mathrm{i}$ 1995 ca. $20 \%$ av innbyggerne i Oslo som flyttet, både over bygrensen og innenfor Oslo (15). FAFOs analyse av flyttemønstre i Oslo med data fra 1991 viste at Indre øst gjennom flyttestrømmenes sosiale sammensetning fikk et netto tilskudd av skilte og av personer med lav utdanning og inntekt, samt at den største delen 
av ikke-vestlige innvandrere flyttet til disse bydelene (16). I 1993 var andelen skilte/separerte i Indre øst ca. $22 \%$ i aldersgruppen 30-49 år og 33\% i gruppen 50-66 år (17). Det er også store forskjeller i andel som er på arbeidsledighets- og uføretrygd i Oslo, med en opphoping i Indre øst $(4,18)$. I en oppfølgingsstudie fra tre fylker i Norge er det vist at skilte/separerte (alder 3549 år) hadde en relativ risiko for totaldød i forhold til gifte på 2,4 for menn og 1,8 for kvinner (19). Videre kan nevnes at bydelen Sagene-Torshov i Indre øst har i overkant av $20 \%$ ett-roms leiligheter og den største konsentrasjonen av kommunale utleieboliger i Oslo (4), som fører til en opphopning av visse selekterte grupper med høyere risiko for å utvikle sykdommer enn andre (17).

Nedgangen i dødelighet for kvinner i Oslo i perioden 1990 til 1996 var svært beskjeden, og den dårlige utviklingen man ser hos kvinnene i Oslo, særlig i Indre øst kan minne om det som er observert i Danmark der det nettopp er kvinnene som i minst grad synes å bedre sin helsesituasjon $(20,21)$. Dette har i stor utstrekning blitt tolket som resultat av en «maskulinisering» av kvinners livsstil (bl.a. røyke- og alkoholvaner) sammen med økende dobbel- og trippelarbeid, og en langvarig periode med høy arbeidsløshet.

Flere nyere studier har vist at forskjeller i sykelighet og dødelighet som kan knyttes til mål på sosial status, både på individnivå og på geografisk nivå, er store både i skandinaviske land og i Oslo $(18,22,23)$. Europeiske sammenlikningsstudier har rapportert om svært store forskjeller i sykelighet og selvopplevd helse mellom individer med høyt og lavt utdanningsnivå i Skandinavia $(22,23)$. Dette blir forklart med at helsepolitikken i de skandinaviske land har fokusert på økonomisk utjevning og har oversett livsstilsrelaterte risikofaktorer som har vært nært knyttet til lavt utdanningsnivå (23). Dødelighetsoppfølging av deltakerne i «Osloundersøkelsen» fra 1974 viste sterke sammenhenger mellom dødelighet og sosioøkonomisk status (utdanning og inntekt) (24).

I Oslohelsa er det vist en sterk samvariasjon på bydelsnivå mellom total dødelighet (20-74 år) i perioden 1991-94 og andel dagligrøykere (40 år) i perioden 1985-88, $r=0,80$ for menn og $r=0,74$ for kvinner (4). Røykedataene er fra 40-årings-undersøkelsen i Oslo fra 1985-88, og det ble her vist at andel dagligrøykere var ca. 50\% i Indre øst og ca. 30\% i Ytre vest både for menn og kvinner $(4,25)$. I bydelene med høyest dødelighet er også utdanningsnivået lavest og arbeidsledigheten høyest. Selv om dette er data på aggregert nivå viser også individdata sterke sammenhenger mellom sosioøkonomiske variable som f.eks. utdanningsnivå og røyking (26).

Tobakksrøyking i befolkningen kan derfor være en viktig delforklaring på den samvariasjon som er vist.
Imidlertid henger røyking også sammen med andre «negative» livsstilsfaktorer som lavt fysisk aktivitetsnivå, høyt fettinntak i kosten og lavt inntak av frukt og grønnsaker, og dette kan i tillegg være med på å forklare forskjeller i dødelighet. For å kunne komme videre $\mathrm{i}$ analysen av hvilke determinanter som er knyttet til variasjonen i dødelighet i tillegg til sigarettrøyking må vi ha fram indidividata for de nevnte variablene. I tillegg må man ha opplysninger om individers sosiale situasjon, deres bruk av helsetjeneste og opplevelse av egenverd.

A bo i et område med lav sosioøkonomisk status har vist seg å være en viktig prediktor for valg av levevaner som f.eks. røyking, selv om man justerer for enkeltindividenes sosioøkonomiske status (28). Opphoping av mennesker med en usunn livsstil i et område vil prege de sosiale og kulturelle normene som er viktige bestemmende faktorer for valg av adferd (28). Det fysiske miljøet kan også ha en viss betydning. Oslohelsa viser at befolkningen i Indre øst er mest utsatt bl.a. for luftforurensning, støy, ulykker og vold (4). Som nevnt tidligere er det spesielt i disse bydelene svært høy flytteaktivitet, og miljøet får derfor ikke vesentlig betydning for innbyggere som bor i bydelene i kortere tid. Dette gjør bl.a. at sammenlikningene mellom bydelene i Oslo og andre europeiske land kan bli noe misvisende.

Vi blir stående med følgende mulige forklaringer på de observerte forskjellene innen Oslo og mellom landene i Europa:

- ulike insidensrater av de store sykdomsgruppene hjerte-karsykdom og kreft.

- forskjellig letalitet ved kroniske fatale sykdommer (ulik kvalitet i helsevesenet, manglende sosialt nettverk, stress på grunn av dårlig økonomi, m.m.).

- selektiv innflytting til billigere bydeler av personer med høyere risiko for å utvikle sykdom (sosialhjelpsklienter, arbeidsledige, uføretrygdede, skilte), eller utflytting av friskere individer til andre regioner og land.

- ulike levekår på grunn av boligforhold, miljø, materielle forhold som arbeidssituasjon, yrke og utdanning.

Dersom «Flere gode leveår for alle» fortsatt er et politisk mål (29) også for de mest utsatte bydeler innen Oslo, trenger vi bedre forskning om hva som skaper de store forskjellene og kunnskap om effekt av forebyggende tiltak mot kjente risikofaktorer.

$V i$ vil takke Statistisk kontor, Byrådsavdeling for finans, Oslo kommune ved Niels H. Gundersen for velvillig assistanse med à skaffe dødelighetsdata. Videre vil vi takke Aage Tverdal, Statens helseundersøkelser for gode faglige innspill til artikkelen. 


\section{REFERANSER}

1. Barstad A. Levekår i by og land. Samfunnsspeilet 1/95. Oslo: Statistisk sentralbyrå, 1995.

2. Gjestland T, Moen E. 'East is east, and west is west... ${ }^{a}$ En sammenliknende unders kelse i Oslo st og Oslo vest i periodene 1890-1940 og 1971-1980. NIBR Rapport 1988:21. Oslo: Norsk institutt for by- og regionforskning.

3. Nasjonalatlas for Norge: Helse. Del I: Helsetilstand. H nefoss: Statens kartverk, 1996.

4. Rognerud M, Stensvold I (red.). Oslohelsa. Utredningen om helse, milj og sosial ulikhet i bydelene.Oslo: Oslo kommune - UllevÂl sykehus, 1998.

5. Thom TJ, Epstein FH, Feldman JJ, Leaverton PE. Trend in total mortality and mortality from heart disease in 26 countries from 1950 to 1978. Int J Epidemiol 1985; 14: 510-20.

6. Bobak M, Marmot M. East-west mortality divide and its potential explanations: proposed research agenda. BMJ 1996; 312: 421-5.

7. Atlas of mortality in Europe. Subnational patterns, 1980/1981 and 1990/1991. WHO Regional Publications, European series, No.75, 1997.

8. Sans S, Kestelhoot H, Kromhout D. The burden of cardiovascular diseases mortality in Europe. Task Force of the European Society of Cardiology on Cardiovascular Mortality and Morbidity Statistics in Europe. Eur Heart J 1997; 18: 1231-48.

9. Statistisk sentralbyrÂ. D dsÂrsaker 1994. OsleKongsvinger, 1997.

10. Smith GD, Dorling D. 'Iím all right, Johna : voting patterns and mortality in England and Wales, 1981-92. BMJ 1996; 313: 1573-7.

11. Kristofersen LB, Borgan J-K, Christie VM. Speilbilder av helsetilstanden i storby. Sosioøkonomiske forskjeller i dødelighet i regioner i Norge og Oslo 1970-1985. NIBR Notat 1989:131. Oslo: Norsk institutt for by- og regionforskning, 1989.

12. Ruberman W, Weinblatt E, Goldberg JD, Chaudhary BS. Psychosocial influences on mortality after myocardial infarction. N Engl J Med 1984; 311: 552-9.

13. Jenkinson CM, Madeley RJ, Mitchell JR, Turner ID. The influence of psychosocial factors on survival after myocardial infarction. Public Health 1993; 107: 305-17.

14. Djuve AB, Bj rnskau T, Hagen K. Fra behov til budsjett. En evaluering av Oslo kommunes kriteriebaserte budsjettfordeling mellom bydelene. FAFO-rapport 210. Oslo: Forskningsstiftelsen FAFO, 1996.

15. Statistisk kontor. Statistisk Ârbok for Oslo 1996. ByrÂdsavdelingen for finans og plan, Oslo kommune, 1996.

16. Hagen K, Djuve AB, Vogt P. Oslo: den delte byen? FAFO-rapport 161. Oslo: Forskningsstiftelsen FAFO, 1994.

17. Barstad A. Store byer, liten velferd? Om segregasjon og ulikhet i norske storbyer. Sosiale og konomiske studier. Oslo: Statistisk sentralbyrÂ, 1997.

18. Rognerud M, Kr,ger ÿ, Gjertsen F, Thelle DS. Strong regional links between socio-economic background factors and disability and mortality in Oslo, Norway. Eur J Epidemiol 1998; 14: 457-63.

19. Selmer RM. Ekteskapelig status, risikofaktorer og d delighet av hjerte-karsykdommer og alle ÂrsakerNor $J$ Epidemiol 1997; 7: 213-9.

20. Sundhedsministeriets Middellevetidsudvalg. Levetiden i Danmark. København, 1994.

21. Sundhedsministeriets Middellevetidsudvalg. Kvinders liv og dødelighed. K benhavn,1994.

22. Machenbach JP, Kunst AE, Cavelaars AEJM, Groenhof F, Geurts JJM. Socioeconomic inequalities in morbidity and mortality in western Europe. Lancet 1997; 394: 1655-9.

23. Cavelaars AEJM, Kunst AE, Geurts JJM, et al. Differences in self reported morbidity by educational level: A comparison of 11 Western European countries. J Epidemiol Community Health 1998; 52: 219-27.

24. Holme I, Helgeland A, Hjermann I, Leren P. Sosio-economic status as a coronary risk factor: the Oslo study. Acta Med Scand Suppl 1982; 660: 147-51.

25. Jenum AK, Thelle DS, Stensvold I, Hjermann I. Regionale ulikheter i sykdomsrisiko i Oslo. R yke- og mosjonsvaner, kroppsmasseindeks, blodlipidnivÂ og blodtrykk blant 40-Âringer 1985-88. Tidsskr Nor LÊgeforen 1998; 118: 23-7.

26. Jacobsen BK, Thelle DS. Risk factors for coronary heart disease and level of education. The Troms heart study. Am J Epidemiol 1988; 127: 923-32.

27. Kleinsmith I, Hill M, Elliot P. Smoking behaviour can be predicted by neighbourhood deprivation measures. $J$ Epidemiol Community Health 1996; 49: 72-7.

28. Bandura A. Social foundations of thought and action. Englewood Cliffs, N.J.: Prentice-Hall, 1986.

29. Sosialdepartementet. Flere gode leveÂr for alle. Forebyggingsstrategier. NOU 1991:10. 